\title{
PENGEMBANGAN MODEL PERLINDUNGAN HUKUM TERHADAP ANAK SEBAGAI KORBAN PERDAGANGAN DI INDONESIA*
}

\author{
Noer Indriati \\ Fakultas Hukum Universitas Jenderal Soedirman \\ Email: indriatiyuwanto@yahoo.co.id
}

\begin{abstract}
Human trafficking is interpreted as a result of a social disorganization and crime caused by the various social factors such as industrialization, rapid social change and modernization. Social changes tend to force women and children to leave their homes and villages to the region or other countries for making a living. Unfortunately, they are not generally equipped themselves by adequate knowledge and education. As a result, human trafficing especially children becomes inevitable. The research employ-ed normative juridical approach. Particularly, this research is descriptive by juridical analytical method. The data source involved primary, secondary and tertiary legal material. Child Legal protectionn has been regulated in legislation in Indonesia, but it is not fully implemented. Victim protection models which are required to develop are (a) placing children in family as well as social houses, where is the environment that gives a sense of security with monitored by officers. (b) giving appropriate restitution or compensation for children necessity.(c) recovering children physical and psychologically through psychiatrist accompaniment and government autho-rities supervision by establishing a practical and sustainable monitoring system. (d) drafting local regulations.
\end{abstract}

Key words: human rights, human trafficking and protection of law

\begin{abstract}
Abstrak
Tindak pidana perdagangan orang ditafsirkan sebagai hasil dari suatu keadaan disorganisasi sosial dan kejahatan diakibatkan oleh berbagai hal yang bersifat sosial, seperti: industrialisasi, perubahan sosial yang cepat dan modernisasi. Perubahan sosial menyebabkan tidak adanya pilihan bagi perempuan dan anak-anak untuk meninggalkan rumah dan desa mereka guna mengais rejeki ke daerah atau negara lain, dengan bekal pengetahuan dan pendidikan yang sangat minim. Hal ini sering menimbulkan perdagangan orang terutama anak. Metode pendekatan yang digunakan pendekatan yuridis normatif atau pendekatan perundang-undangan. Perlindungan hukum terhadap anak telah diatur dalam peraturan perundang-undangan di Indonesia, tetapi penerapannya belum optimal. Model perlindungan korban yang tepat untuk dikembangkan adalah: (a) Menempatkan anak di dalam keluarga dan panti sosial, dimana merupakan lingkungan yang memberi rasa aman dengan dimonitor oleh petugaspetugas. (b) Pemberian restitusi atau ganti rugi yang benar-benar diterima demi kepentingan anak. (c) Pemulihan kondisi fisik maupun psikhis anak dengan pendampingan psikhiater dan pengawasan oleh aparat pemerintah sehingga diperlukan sistem monitoring yang praktis dan berkesinambungan. (d) Pembuatan Peraturan Daerah.
\end{abstract}

Kata kunci: Hak asasi manusia, perdagangan orang dan perlindungan hukum

Pendahuluan

Abad ke-21 merupakan abad globalisasi yang dipenuhi dengan ancaman-ancaman dan tantangan global. Tindak pidana perdagangan orang atau yang dikenal dengan trafficking in person/human trafficking telah menjadi feno-

- Artikel ini merupakan hasil penelitian mandiri berdasarkan Keputusan Dekan Fakultas Hukum Nomor Kept. 149/ UN.23.05/DT.01.00/2014 mena global yang terjadi di hampir seluruh negara di dunia, dengan tingkat kesulitan yang berbeda-beda. Fenomena ini tdak hanya merupakan fenomena sosial biasa melainkan telah menjadi fenomena pelanggaran hukum dan hak asasi manusia. 
Tindak pidana perdagangan orang selalu menimbulkan akibat yang sangat serius bagi korban dan keluarganya, masyarakat maupun negara. Berbagai kondisi negara yaitu negara yang menjadi negara tujuan perdagangan orang, negara transit atau negara sumber terjadinya perdagangan orang, seperti yang dialami Indonesia. Anak-anak merupakan korban yang paling mudah dan sangat rentan. Hal ini menempatkan mereka pada posisi yang sangat memiliki resiko yang tinggi, misal: dalam kaitannya dengan kesehatan, tekanan-tekanan dan kekerasan baik berupa fisik maupun mental, yang akan mengancam kualitas dari generasi penerus Negara Republik Indonesia.

Perdagangan orang merupakan bentuk perbudakan baru, yang terjadi di jaman modern dengan tujuan hidup biaya murah tetapi akan mendapatkan keuntungan besar (big profits and cheap lives). ${ }^{1}$ Pada kasus-kasus perdagangan orang atau human trafficking terutama perempuan dan anak merupakan fenomena gunung es, dimana kasus-kasus yang tidak atau bahkan belum muncul ke permukaan jauh lebih banyak. Kementerian Luar Negeri mencatat data korban tindak pidana perdagangan orang yang diperoleh dan ditangani oleh seluruh per-wakilan Republik Indonesia di Luar Negeri sepanjang tahun 2010 sebanyak 35 orang yang berasal dari KBRI Doha, KBRI Kuala Lumpur, KJRI Kinabalu, KJRI Penang, dan KBRI Singapura. Pada 2011 tercatat sebanyak 33 orang dan melonjak pada tahun 2012 sebanyak 92 orang.

Usaha masyarakat internasional atau negara-negara dalam upaya mencegah dan memberantas kejahatan transnasional dan kejahatan internasional dilakukan dengan kerjasama secara fisik, yaitu menuangkan pengaturannya dalam konvensi internasional. Protokol Perdagangan Orang Pasal $3 \mathrm{c}$ menjelaskan bahwa unsur cara tidak berlaku bagi korban anak. Unsur cara dalam Undang-undang No. 21 Tahun 2007 tentang Pemberantas Tindak Pidana Perdagang-

\footnotetext{
Pendapat yang menyebutkan bahwa perdagangan orang dewasa ini identik dengan perbudakan dalam era modern. Lihat dalam Noel B. Busch-Armendariz, Maura B. Nsonwu dan Laurie Cook Heffron, "Human Trafficking Victims and Their Children: Assessing Needs, Vulnerabi-
}

an Orang (UU. No. 21 Tahun 2007 tentang PTPPO) tidak diatur sehingga perlakuan korban anak diperlakukan sebagaimana orang dewasa. Berdasar Pasal 6 Protokol Perdagangan Orang mengatur bahwa harus ada perlindungan khusus terhadap anak sebagai korban tetapi dalam perundang-undangan Indonesia belum tercermin adanya pengaturan tersebut. Protokol Perdagangan Orang, dalam Pasal 6 ayat 4 mengatur mengenai bantuan dan perlindungan korban perdagangan orang menyebutkan bahwa "Setiap negara pihak harus mempertimbangkan umur, jenis kelamin dan kebutuhan khusus korban perdagangan orang, khususnya kebutuhan khusus anak-anak, meliputi: perumahan, pendidikan dan perawatan dalam menerapkan ketentuan pasal ini”.

Setiap Negara Pihak harus menjamin dalam sistem hukum nasionalnya untuk mengambil langkah-langkah perlindungan korban perdagangan orang untuk memperoleh kompensasi atas kerugian yang diderita. Kompensasi yang diberikan seringkali tidak sebanding dengan kondisi korban, dan restitusi yang diberikan tidak mengatur tolak ukur pemberian tersebut sehingga tidak memberikan keadilan kepada korban. Kompensasi, restitusi atau ganti rugi yang seharusnya diperoleh anak melalui ahli warisnya belum berjalan sebagaimana mestinya. Selanjutnya perlindungaan korban dalam protokol perdagangan orang diatur dalam Pasal 7 dan Pasal 8. Pasal 8 (4) menyebutkan negara wajib memfasilitasi pemulangan korban yang tidak mempunyai dokumen dan harus setuju untuk mengeluarkannya dokumen terhadap korban bila korban tidak mempunyai dokumen. Pemu-langan korban yang tidak memiliki dokumen sebagaimana tercantum dalam Pasal 8 Protokol Perdagangan Orang juga belum terakomodir dalam UU. No. 21 Tahun 2007 tentang PTPPO.

Perlindungan terhadap anak sebagai korban tindak pidana perdagangan orang yang dituangkan dalam UU. No. 21 Tahun 2007 tentang PTPPO, Bab V mengatur perlindungan saksi dan

lities, Strengths, and Survivorship", 3-15-2011, Journal of Applied Research on Children: Informing Policy for Children at Risk, Volume 2, Issue 1 Human Trafficking, Article 3, Published by DigitalCommons@ The Texas Medical Centre, 2011. 
korban, Pasal 43 menyebutkan bahwa perlindungan terhadap saksi dan korban dalam tindak pidana perdagangan orang dilaksanakan berdasarkan UU No. 13 Tahun 2006 tentang Perlindungan Saksi dan Korban. Undang-undang tersebut tidak menunjukkan secara tegas bahwa anak sebagai korban tindak pidana perdagangan yang juga berhak mendapatkan perlindungan, kebutuhan khusus anak juga belum dapat dipenuhi. Pasal 5 (ayat 2) menyebutkan bahwa "ayat 1 pasal ini berlaku hanya untuk kasus-kasus tertentu antara lain: tindak pidana korupsi, tindak pidana narkotika/psikotropika, tindak pidana terorisme, dan tindak pidana lain yang mengakibatkan posisi saksi dan korban dihadapkan pada situasi yang sangat membahaya-kan jiwanya".

Perlindungan terhadap anak merupakan suatu usaha yang menciptakan kondisi dimana setiap anak dapat memperoleh hak-haknya. Melindungi anak adalah juga melindungi manusia, dengan kata lain melindungi manusia seutuhnya. Pasal 1 ayat 2 UU. No. 23 Tahun 2002 tentang Perlindungan Anak mengatur definisi perlindungan anak adalah segala kegiatan untuk menjamin dan melindungi anak dan hak-haknya agar dapat hidup, tumbuh, berkembang dan berpartisipasi, secara optimal sesuai dengan harkat dan martabat kemanusiaan, serta mendapat perlindungan dari kekerasan dan kemiskinan.

Problem sosial anak yang bermasalah tidak hanya menjadi masalah nasional saja, tetapi juga masalah internasional. Indonesia sebagai negara yang telah meratifikasi Konvensi Hakhak Anak 1989, dengan Keputusan Presiden No. 36 Tahun 1990 (Lembaran Negara Nomor 57 Tahun 1990) tentang Pengesahan Convention on the Rights of the child 1989, memiliki kewajiban untuk mewujudkan sistem perlindungan terhadap anak secara nyata dan berkesinambungan termasuk terhadap anak yang bermasalah. Kenyataan menunjukkan bahwa anak-anak di berbagai belahan dunia mengalami kelaparan, kekerasan, dan ditelantarkan serta diperdagangkan.
Kemiskinan menjadi faktor pendorong masyarakat untuk bermigrasi dan mencari alternatif penghasilan di luar desa, daerah maupun negara dimana mereka berasal. Meskipun angka kemiskinan telah menurun pada tahun 2010 dari 14,2\% menjadi 13,3\%, ternyata tidak secara signifikan menurunnya jumlah korban perdagangan orang di Indonesia. Lemahnya daya tangkal individu dan keluarga dalam mencegah terjadinya perdagangan orang menyebabkan orang mudah terjebak menjadi korban. Kemiskinan, rendahnya tingkat pendidikan, keinginan mendapatkan gaji tinggi untuk dapat memenuhi kebutuhan hidup yang mahal, perubahan gaya hidup (life style) turut memperlemah daya tangkal individu.

Meningkatnya pengangguran di pedesaan akibat eksploitasi lahan dan berkembangnya industri yang kurang memperhatikan aspek lingkungan, menyebabkan orang kehilangan mata pencahariannya. Eksploitasi tersebut menyebabkan tidak adanya pilihan bagi perempuan dan anak-anak untuk meninggalkan rumah dan desa mereka guna mengais rejeki ke daerah atau negara lain, dengan bekal pengetahuan dan pendidikan yang sangat minim.

\section{Permasalahan}

Dari latar belakang masalah yang telah diuraikan di atas, akan dibahas bagaimana pengembangan model perlindungan hukum yang tepat terhadap anak sebagai korban perdagangan orang di Indonesia.

\section{Metode Penelitian}

Tipe penelitian adalah penelitian hukum normatif (legal research), yaitu dalam bentuk penelitian inventarisasi hukum-hukum positif yang dilakukan dengan mengkaji kaidah-kaidah hukum atau asas-asas hukum. ${ }^{2}$ Penelitian hukum normatif atau penelitian hukum doktrinal juga merupakan penelitian hukum kepustakaan. Peneliti melakukan inventarisasi terhadap konvensi-konvensi internasional, protokol dan peraturan perundang-undangan yang berlaku di 
Indonesia, yang berhubungan dengan perdagangan anak atau trafficking of child dan perlindungannya terhadap anak mulai dari UUD 1945, undang-undang sampai dengan peraturan pelaksanaannya. Penelitian hukum normatif ini dilakukan terhadap sinkronisasi atau harmonisasi hukum dari bahan-bahan hukum yang telah diperoleh.

Metode pendekatan yang digunakan pendekatan yuridis normatif atau pendekatan perundang-undangan. Sebagai spesifikasi penelitian adalah penelitian deskriptif yuridis analitis, dengan sumber data berupa bahan hukum primer, sekunder dan tertier, serta yang didukung dengan data primer, dan dianalisis secara juridis kualitatif.

\section{Pembahasan}

Penyelenggaraan perlindungan anak merupakan kewajiban dan tanggung jawab negara, pemerintah, masyarakat, keluarga dan orang tua yang meliputi perlindungan di bidang agama, pendidikan, kesehatan dan sosial. Upaya perlindungan hukum terhadap anak, baik anak lakilaki maupun perempuan dilakukan melalui pencegahan \& pemberantasan perdagangan orang.

Kualitas perlindungan terhadap anak hendaknya memiliki derajat atau tingkat yang minimal sama dengan perlindungan terhadap orang-orang dewasa perempuan maupun pria, karena setiap orang memiliki kedudukan yang sama di depan hukum (equality before the law). Masalahnya perlindungan yang harus di-berikan tidak semata-mata bisa didekati secara yuridis, tetapi perlu pendekatan yang lebih luas, yaitu: ekonomi, sosial dan budaya, serta psikhologis.

Perdagangan orang dan eksploitasi seksual merupakan masalah sosial yang sangat besar. Secara rutin anak diperdagangkan sebagai komoditas yang menghasilkan milyaran dolar yang di kendalikan dengan mengabaikan akibat yang ditimbulkan. ${ }^{3}$ Perlindungan hukum bagi anak-anak merupakan satu sisi upaya pendekatan untuk melindungi anak-anak Indonesia.

Yvonne Rafferty, "The Impact of Trafficking on Children: Psychological and Social policy Perspectives", Journal Compilation: Child Development Perspectives, Volume 2, Number 1, 2008, hlm. 1.
Konvensi tindak pidana transnasional terorganisasi 2000, enforcement-nya tidak pada tingkat hukum internasional, melainkan pada tingkat hukum nasional karena berlaku di dalam wilayah suatu negara dan bersentuhan langsung dengan kepentingan hukum warga Negara (individu). Perjanjian seperti ini sering disebut dengan standard/harmonized-setting treaties. ${ }^{4}$ Perjanjian demikian tidak menciptakan norma, akan tetapi hanya mewajibkan Negara untuk menciptakan norma itu di dalam hukum nasionalnya.

Pada Pasal 5 (ayat 2) Protokol Perdagangan Orang disebutkan bahwa Setiap Negara Pihak wajib mengambil langkah-langkah legis-lasi dan tindakan lainnya yang dianggap perlu (1) untuk ditetapkan sebagai tindak pidana: berdasarkan hukum nasionalnya, mencoba untuk melakukan suatu kriminalisasi yang ditetapkan sesuai dengan ayat 1 pasal ini; (2) berpartisipasi dalam suatu kejahatan yang dibentuk sesuai dengan ayat 1 pasal ini; dan (3) menyelenggarakan atau mengarahkan orang lain untuk melakukan suatu kejahatan sesuai dengan ayat 1 pasal ini.

Tindakan-tindakan efektif (effective actions) untuk mencegah dan memberantas perdagangan orang, khususnya perempuan dan anak-anak, memerlukan pendekatan internasional yang komprehensif di negara-negara asal, transit dan tujuan (the countries of origin, transit and destination), yang meliputi langkahlangkah untuk mencegah peredaran tersebut, untuk menghukum pelaku human trafficking (traffickers) dan melindungi para korban (the victims) perdagangan, termasuk dengan melindungi manusia yang hak-hak mereka diakui secara internasional. Penentuan perdagangan orang dipengaruhi oleh tingginya permintaan tenaga kerja wanita. Permintaan akan wanita untuk kebutuhan prostitusi sangat tinggi sehingga menimbulkan isu pelanggaran hak asasi, atau ekonomi yang disebabkan adanya kesenjangan ekonomi antara negara-negara di dunia. $^{5}$

4 Damos Dumoli Agusman, 2010, Hukum Perjanjian Internasional - Kajian Teori dan Praktik Indonesia, Bandung: Refika Aditama, hlm. 100.

5 Phyllis Coontz and Catherine Griebel, “International Ap- 
Pasal 54 Konvensi Hak Anak menetapkan hak-hak anak yang disertai dengan dua Protokol Opsional. Konvensi memerinci HAM pada anak bahwa anak-anak di mana-mana memiliki: hak untuk kelangsungan hidup; hak untuk mengembangkan potensi sepenuhnya; hak untuk mendapatkan perlindungan dari pengaruh-pengaruh buruk, pelecehan dan eksploitasi, dan hak untuk berpartisipasi sepenuhnya dalam keluarga, masyarakat dan kehidupan sosial.

Ada beberapa hak anak dalam Konvensi Hak Anak yang dapat diuraikan sebagai berikut. Pertama, hak terhadap kelangsungan hidup (survival rights). ${ }^{6} \mathrm{Hak}$ terhadap kelangsungan hidup, berupa hak anak untuk melestarikan dan mempertahankan hidup dan hak untuk memperoleh standar pelayanan kesehatan tertinggi dan perawatan medis yang sebaik-baiknya. Konsekuensi menurut Konvensi Hak Anak 1989, negara harus menjamin kelangsungan hak hidup yang layak, kelangsungan hidup dan perkembangan anak (Pasal 6). Di samping itu, negara berkewajiban untuk menjamin hak atas taraf kesehatan tertinggi yang bisa dijangkau, dan melakukan pelayanan kesehatan serta pengobatan, khususnya perawatan kesehatan primer (Pasal 24).

Implementasi Pasal 24, negara berkewajiban untuk melaksanakan program-program sebagai berikut: (a) melaksanakan upaya penurunan angka kematian bayi dan anak; (b) menyediakan pelayanan kesehatan yang diperlukan; (c) memberantas penyakit dan kekurangan gizi; (d) menyediakan pelayanan kesehatan sebelum dan sesudah melahirkan bagi ibu; (e) memperoleh informasi dan akses pada pendidikan, serta mendapatkan dukungan pada pengetahuan dasar tentang kesehatan dan gizi; (f) mengembangkan perawatan kesehatan guna pencegahan, bimbingan bagi orang tua, serta penyuluhan keluarga berencana; dan (g) mengambil tindakan untuk menghilangkan praktik tradisional yang

proaches to Human Trafficking: The Call for a GenderSensitive Perspective in International Law", Women's Health Journal, Vol. 4, 2004, hlm. 51.

6 Geraldine Van Bueren mengatakan bahwa setiap orang/ anak berhak untuk hidup dan dilindungi oleh hukum, dan menimbulkan prasangka buruk terhadap pelayanan kesehatan.

Terkait dengan hal tersebut, maka hak anak akan kelangsungan hidup dapat berupa: (a) Hak anak untuk mendapatkan nama dan kewarganegaraan semenjak dilahirkan (Pasal 7); (b) Hak anak untuk memperoleh perlindungan dan memulih-kan kembali aspek dasar jati diri anak (yang berkaitan dengan nama, kewarganegaraan dan ikatan keluarga) (Pasal 8); (c) Hak anak untuk hidup bersama (Pasal 9), dan Hak anak untuk memperoleh perlindungan dari segala bentuk salah perlakuan (abuse) yang dilakukan orang tua atau orang lain yang bertanggung jawab atas pengasuhan (Pasal 19); (d) Hak anak untuk memperoleh perlindungan khusus bagi anak-anak yang kehilangan lingkungan keluarganya dan menjamin penguasaan keluarga atau penempatan institusional yang sesuai dengan mempertimbangkan latar belakang budaya anak (Pasal 20); (e) Adopsi terhadap anak hanya dibolehkan dan dilakukan demi kepentingan terbaik anak, dengan segala perlindungan yang disahkan oleh pejabat yang berwenang (Pasal 21); (f) Hak-hak anak penyandang cacat (disabled) untuk memperoleh pengasuhan, pendidikan dan latihan khusus yang dirancang untuk membantu mereka demi mencapai tingkat kepercayaan diri yang tinggi (Pasal 23); dan (g) Hak anak un-tuk menikmati standar kehidupan yang mema-dai dan hak atas pendidikan (Pasal 27 dan 28).

Kedua, hak terhadap perlindungan (protection rights). Hak terhadap perlindungan yaitu perlindungan anak dari diskriminasi, tindak kekerasan dan menterlantarkan anak yang tidak mempunyai keluarga, dan bagi anak pengungsi. Hak perlindungan dari diskriminasi, termasuk: (a) Perlindungan anak penyandang cacat untuk memperoleh pendidikan, perawatan dan latihan khusus; dan (b) Hak anak dari kelompok masyarakat minoritas dan penduduk asli dalam kehidupan masyarakat pada suatu negara.

tidak seorangpun dapat dirampas hak hidupnya di pengadilan. Lihat dalam Geraldine Van Bueren, The International Law on the Rights of the Child, International Studies in Human Rights Volume 35, 1998, Martinus Nijhoff Publishers, hlm. 58. 
Perlindungan dari ekploitasi, meliputi: (a) Perlindungan dari gangguan kehidupan pribadi; (b) Perlindungan dari keterlibatan dalam pekerjaan yang mengancam kesehatan, pendidikan dan perkembangan anak; (c) Perlindungan dari penyalahgunaan obat bius dan narkoba; (d) Perlindungan dari upaya penganiayaan seksual, prostitusi, dan pornografi; (e) Perlindungan dari upaya penjualan, penyelundupan dan penculikan anak; (f) Perlindungan dari proses hukum bagi anak yang didakwa atau diputus telah melakukan pelanggaran hukum.

Ketiga, hak untuk tumbuh berkembang (development rights). Hak untuk tumbuh berkembang meliputi segala bentuk pendidikan (baik formal maupun non formal) dan hak untuk mencapai standar hidup yang layak bagi perkembangan fisik, mental, spiritual, moral dan sosial anak. Hak anak atas pendidikan diatur pada Pasal 28 Konvensi Hak Anak 1989, yang menyebutkan: (a) negara menjamin kewajiban pendidikan dasar dan menyediakan secara cuma-cuma; (b) mendorong pengembangan macam-macam bentuk pendidikan dan yang mudah dijangkau oleh setiap anak; (c) membuat informasi dan bimbingan pendidikan serta keterampilan bagi anak; dan (d) mengambil langkah-langkah untuk mendorong kehadirannya secara teratur di sekolah dan pengurangan angka putus sekolah.

Berkaitan dengan hal tersebut, meliputi: (a) Hak untuk memperoleh informasi; (b) Hak untuk bermain dan berekreasi; (c) Hak untuk berpartisipasi dalam kegiatan budaya; (d) Hak untuk kebebasan berpikir dan beragama; (e) Hak untuk mengembangkan kepribadian; (f) Hak untuk memperoleh identitas; (g) Hak untuk didengar pendapatnya; dan (h) Hak untuk memperoleh pengembangan kesehatan dan fisik.

Keempat, hak untuk berpartisipasi (participation rights). Hak anak untuk berpartisipasi yaitu hak untuk menyatakan pendapat dalam segala hal yang mempengaruhi anak. Hak yang terkait dengan hal tersebut, meliputi: (a) Hak

Michael D. A. Freeman, 1997, The Moral Status of Children: Essays on the Rights of the Child, Martinus Nij-hoff Publishers, hlm.10.

8 Christine Bruckert, and Colette Parent, 2002. "Traffic- anak untuk mengeluarkan pendapat dan memperoleh pertimbangan atas pendapatnya; (b) Hak anak untuk mendapat dan mengetahui informasi serta untuk mengekpresikannya; (c) Hak anak untuk berserikat menjalin hu-bungan untuk bergabung; dan (d) Hak anak untuk memperoleh informasi yang layak dan terlindung dari informasi yang tidak sehat.

Michael D. A. Freeman menyatakan bahwa hak-hak anak untuk memiliki kebebasan berserikat dan kebebasan berkumpul, hanya tunduk pada pembatasan yang diperlukan dalam suatu masyarakat yang demokratis untuk kepentingan keamanan nasional, keselamatan publik, ketertiban umum, perlindungan kesehatan publik atau moral atau melindungi hak-hak dan kebebasan-kebebasan orang lain. ${ }^{7}$

Konsep "perdagangan orang" atau "penyelundupan orang", dimana salah satu parameter ditempatkan pada kedudukan korban tindak pidana terorganisasi yang merupakan fenomena dalam pembangunan. ${ }^{8}$ Model perlindungan yang diatur dalam protokol diserahkan kepada masing-masing negara pihak perjanjian. Protokol mewajibkan kepada negara sebagai pihak untuk mengambil tindakan lain dan langkah-langkah legislasi sebagai bentuk perlindungan korban, antara lain: (a) melindungi privasi dan kerahasiaan identitas korban perdagangan orang; (b) memberikan informasi dan bantuan dalam proses hukum; (c) memberikan bantuaan berupa penanganan psikhis dan pemulihan fisik korban, khususnya kebutuhan khusus anak; (d) memberikan kompensasi atas kerugian yang diderita; (e) mengizinkan korban untuk tetap tinggal di wilayahnya, sementara atau permanen dengan mendasarkan pada kemanusiaan; (f) negara harus memfasilitasi pemulangan korban tanpa penundaan yang tidak semestinya, dalam hal korban tidak memiliki dokumen maka negara penerima harus setuju untuk menerbitkannya; dan (g) mengadakan perjanjian bilateral maupun multilateral dengan negara lain terutama dalam pemulangan korban.

king In Human Beings and Organized Crime: A Literature Review", Research and Evaluation Branch Community, Contract and Aboriginal Policing Services Directorate Royal Canadian Mounted Police. 
Keinginan untuk mencegah dan menanggulangi tindak pidana perdagangan anak didasarkan pada nilai-nilai luhur, komitmen nasional dan internasional untuk melakukan upaya pencegahan sejak dini, penindakan terhadap pelaku, perlindungan korban dan peningkatan kerjasama. Selanjutnya Arif Gosita mengatakan bahwa dasar pelaksanaan perlindungan anak adalah sebagai berikut. ${ }^{9}$ Pertama, dasar filosofis. Pancasila dasar kegiatan dalam berbagai bidang kehidupan keluarga, bermasyarakat, bernegara, dan berbangsa, serta dasar filosofis pelaksanaan perlindungan anak. Kedua, dasar etis; pelaksanaan perlindungan anak harus sesuai dengan etika profesi yang berkaitan, untuk mencegah perilaku menyimpang dalam pelaksanaan kewenangan, kekuasaan, dan kekuatan dalam pelaksanaan perlindungan anak. Ketiga, dasar yuridis; pelaksanaan perlindungan anak harus didasarkan pada UUD 1945 dan berbagai peraturan perundang-undangan lainnya yang berlaku. Penerapan dasar yuridis ini harus secara integratif, yaitu penerapan terpadu menyangkut peraturan perundang-undangan dari berbagai bidang hukum yang berkaitan.

Sejarah bangsa Indonesia hingga kini mencatat berbagai penderitaan, kesengsaraan dan kesenjangan sosial, yang disebabkan oleh perilaku tidak adil dan diskriminatif atas dasar etnik, ras, warna kulit, budaya, bahasa, agama, golongan, jenis kelamin dan status sosial lainnya. Perilaku tidak adil dan diskriminatif tersebut merupakan pelanggaran hak asasi manusia, baik yang bersifat vertikal (dilakukan oleh aparat negara terhadap warga negara atau sebaliknya), maupun horizontal (antar warga negara sendiri) dan tidak sedikit yang masuk dalam kategori pelanggaran hak asasi manusia yang berat (gross violation of human rights).

Abdul Hakim Garuda Nusantara mengatakan, ${ }^{10}$ bahwa perlindungan hukum bagi anakanak merupakan satu sisi pendekatan untuk melindungi anak-anak Indonesia. Masalahnya tidak semata-mata bisa didekati secara yuridis, tetapi

\footnotetext{
Arif Gosita, 1999, “Aspek Hukum Perlindungan Anak dan Konvensi Hak-hak Anak", Era Hukum, Jurnal IImiah Ilmu Hukum, No. 4/Th.V/April 1999, Fakultas Hukum Tarumanegara, Jakarta, hlm. 264-265.
}

perlu pendekatan yang lebih luas, yaitu: ekono$\mathrm{mi}$, sosial dan budaya. Oleh karena itu, pendekatan dari sisi korban juga diperlukan sebagai bentuk pendekatan secara sosial, ekonomi dan budaya. Pada umumnya, orang tidak dapat memikirkan adanya kejahatan tanpa ada korbannya, karena pelaku dan korban bagaikan dua sisi mata uang.

Arif Gosita mengatakan bahwa korban adalah mereka yang menderita jasmaniah dan rohaniah sebagai akibat tindakan orang lain yang mencari pemenuhan kepentingan atau kebutuhan diri sendiri atau orang lain yang bertentangan dengan kepentingan dan hak asasi yang menderita. Adapun kebutuhan-kebutuhan korban yang sangat diperlukan, antara lain: (1) kebutuhan keamanan sehingga kejahatan tidak terulang lagi; (2) kebutuhan restitusi dan kompensasi, baik dirinya sendiri maupun untuk orang-orang yang tergantung hidupnya dari korban; (3) kebutuhan pelayanan kesehatan, konseling dan pelayanan lain; (4) kebutuhan partisipasi aktif dalam proses peradilan, baik sebagai saksi ataupun korban; dan (5) kebutuhan untuk menghilangkan rasa takut.

Menurut Muladi dan Barda Nawawi Arief terdapat dua model perlindungan, yaitu: model hak-hak prosedural (the procedural right model) dan model pelayanan (the service model). Model hak-hak prosedural (the procedural right model), menekankan korban berperan aktif di dalam proses peradilan pidana. Model pelayanan (the service model) menekankan pada pemberian ganti kerugian dalam bentuk kompensasi, restitusi, dan upaya pengembalian kondisi korban yang mengalami trauma, rasa takut, dan tertekan akibat kejahatan sehingga diperlukan standar baku bagi pembinaan korban yang dapat digunakan oleh polisi. Korban akan merasa dijamin kembali kepentingannya dalam suasana tertib sosial yang adil. Model ini dapat menghemat biaya sebab adanya pedoman bantuan yang baku, serta mempertimbangkan kerugian-kerugian yang dialami korban. Model perlindungan

10 Widiartana, 2009, Viktimologi Perspektif Korban Penanggulangan Kejahatan, Yogyakarta: Universitas Atma Jaya, hlm. 19. 
terhadap anak korban tindak pidana perdagangan lebih sesuai dengan model pelayanan, yang dilakukan dengan pemberian ganti kerugian dalam bentuk kompensasi, restitusi, dan upaya pengembalian kondisi korban yang mengalami trauma, rasa takut, dan tertekan akibat kejahatan. Pemulihan kondisi anak sebagai korban akan lebih sulit dilakukan dan memakan waktu yang lama.

UU No. 21 Tahun 2007 tentang PTPPO dilengkapi dengan PP. No. 9 Tahun 2008 tentang Tata Cara dan Mekanisme Pelayanan Terpadu Bagi Saksi dan/atau Korban Tindak Pidana perdagangan orang, yang di dalam Pasal 4 disebutkan bahwa dalam hal saksi dan/atau korban adalah anak, maka pelayanan diberikan secara khusus sesuai dengan kepentingan terbaik bagi anak. Selanjutnya di dalam penjelasannya diuraikan bahwa ketentuan ini dimaksudkan agar standar pelayanan minimal dan standar operasional prosedur pemulangan dan reintegrasi sosial terhadap anak sebagai saksi dan/atau korban ditentukan sesuai dengan prinsip konvensi hak anak, antara lain prinsip nondiskriminasi dan kepentingan terbaik bagi anak.

Perlindungan terhadap anak sebagai korban perdagangan orang, berdasarkan UU. No. 21 Tahun 2007 tentang PTPPO, Bab V, Pasal 43 menyebutkan perlindungan saksi dan korban tindak pidana dilaksanakan berdasarkan UU. No. 13 Tahun 2006 tentang Perlindungan Saksi dan Korban. Model perlindungan berdasarkan UU. No. 21 Tahun 2007 tentang PTPPO tidak membedakan antara anak dengan orang dewasa, Pasal 44 menjelaskan bahwa korban diberikan hak untuk kerahasiaan identitas korban dan saksi, serta keluarganya sampai derajat kedua. Pasal 47 memberikan tugas kepada Kepolisian Negara Republik Indonesia untuk memberikan perlindungan, baik sebelum, selama, maupun sesudah proses pemeriksaan perkara.

Anak sebagai korban perdagangan orang merupakan perampasan terhadap hak-hak, se-

11 Susan Tiefenbrun, "Child Soldiers, Slavery and the Trafficking of Children", Fordham International Law Journal, Volume 31, Issue 2, Article 6, 2007, The Ber-kely Electronic Press (bepress), hlm. 449.

12 Ira Colby, "Runaway and Throwaway Youth: Time for perti: kebebasan bergerak, kebebasan berkumpul dan kebebasan memiliki serta kebebasan bersenang-senang atau bermain. ${ }^{11}$ Kehidupan anak di jalan sangat mempengaruhi partumbuhan fisik, sosial, emosional dan kesehatan. Khusus untuk anak terdapat beberapa pengalaman terhadap tumbuh dengan resiko yang tinggi, termasuk: ${ }^{12}$ (a) tidak dapat dilindunginya dari eksploitasi seksual, dan obat terlarang; (b) Kurang gizi, depresi dan kurang percaya diri; dan (c) Tidak mendapatkan pendidikan yang baik da kehidupan yang layak serta perlindungan terhadap dirinya.

Pasal 57 ayat (1) Pemerintah, Pemerintah Daerah, masyarakat dan keluarga wajib mencegah terjadinya tindak pidana perdagangan orang, sedangkan ayat (2) Pemerintah dan Pemerintah Daerah wajib membuat kebijakan, program, kegiatan, dan mengalokasikan anggaran untuk melaksanakan pencegahan dan penanganan masalah perdagangan orang.

Model perlindungan korban yang tepat untuk dapat dikembangkan sebagai berikut. Pertama, menempatkan anak di dalam keluarga dan panti sosial, dimana merupakan lingkungan yang memberi rasa aman dengan dimonitor oleh petugas-petugas, yang telah ditentukan oleh pemerintah daerah sehingga anak tidak lagi menjadi korban.

UU. No. 23 Tahun 2002 tentang Perlindungan Anak, Pasal 3 Perlindungan Anak bertujuan untuk menjamin terpenuhinya hak-hak anak agar dapat hidup, tumbuh, berkembang, dan berpartisipasi secara optimal sesuai dengan harkat dan martabat kemanusiaan, serta mendapat perlindungan dari kekerasan dan diskriminasi, demi terwujudnya anak Indonesia yang berkualitas, berakhlak mulia dan sejahtera. Pasal 7 ayat (1) menyebutkan bahwa setiap anak berhak untuk mengetahui orang tuanya, dibesarkan, dan diasuh oleh orang tuanya sendiri. Pasal 47-nya menyebutkan: (1) Negara, pemerintah, keluarga, dan orang tua wajib melindungi anak dari upaya

Policy Changes and Public Responsibility", 3-15-2011, Journal of Applied Research on Children: Informing Policy for Children at Risk, Volume 2, Issue 1: Human Trafficking, Article 4, 2011, Published by Digital Commons@The Texas Medical Centre, hlm. 6. 
transplantasi organ tubuhnya untuk pihak lain; dan (2) Negara, pemerintah, keluarga, dan orang tua wajib melindungi anak dari perbuatan: (a) pengambilan organ tubuh anak dan/atau jaringan tubuh anak tanpa memperhatikan kesehatan anak; (b) jual beli organ dan/atau jarringan tubuh anak; dan (c) penelitian kesehatan yang menggunakan anak sebagai objek penelitian tanpa seijin orang tua dan tidak mengutamakan kepentingan yang terbaik bagi anak. Pasal-pasal tersebut menunjukkan bahwa orang tua mempunyai tanggung jawab penuh atas tumbuh kembang dan perlindungan terhadap anak.

Kemiskinan menjadi faktor utama seseorang anak diperdagangkan dan keinginan orang tua untuk menyerahkan anaknya kepada orang kaya di luar negeri dengan harapan diadopsi sehingga kehidupan anaknya menjadi lebih baik. Orang tua, suami, saudara/kerabat, tetangga, teman memang dapat terlibat sebagai orangorang yang menjual, apabila di dalam perekrutan mereka dilakukan dengan menggunakan kebohongan, penipuan, rayuan, paksaan.

Penempatan anak di dalam keluarga akan memberikan rasa aman bagi anak yang telah menjadi korban perdagangan orang. Apabila pihak keluarga atau orang tua diduga sebagai pelaku tindak pidana perdagangan orang, maka dapat dilakukan koordinasi dengan pihak kepolisian terkait untuk melindungi korban (khususnya salah satu pelaku berada di daerah korban). Hal ini ditindaklanjuti dengan membuat surat perjanjian bahwa orang tua tidak akan mengulang perbuatannya di depan petugas kepolisian yang disaksikan oleh pendamping, petugas RT/RW/Kelurahan dan tokoh masyarakat setempat.

Berdasarkan Peraturan Menteri Kesehatan Republik Indonesia No. 1259/Menkes/SK/XII/ Tahun 2009 pada lampiran b. 2. disebutkan bahwa Panti sosial meliputi: balai, lembaga, rumah singgah, yayasan/panti sosial, rumah perlindungan yang menangani anak, lanjut usia, korban napza, orang dengan kecacatan, gelandangan/pemulung/pengemis, korban tindak pidana perdagangan orang, orang dengan HIV dan Aids, dan bekas binaan lembaga pemasyarakat- an. Penempatan anak dan perawatan anak yang menjadi korban perdagangan di panti sosial, berdasarkan UU. No. 11 Tahun 2009 tentang Kesejahteraan Sosial dapat mengakses pendanaan dari jamkesmas yang bersumber dari Anggaran Pendapatan dan Belanja Negara (APBN) dan Daftar Isian Pelaksanaan Anggaran (DIPA), Satuan Kerja Pemerintah Daerah (SKPD) Sosial, SKPD Tenaga Kerja dan Transmigrasi, LSM yang berkoordinasi dengan SKPD Sosial setempat, dengan melampirkan surat ketera-ngan sebagai penghuni balai, rumah singgah, yayasan, panti sosial dimana korban menda-patkan pelayanan. Apabila rehabilitasi sosial dilakukan oleh lembaga swadaya masyarakat, maka pendanaan dapat diperoleh dari APBN yang berkoordinasi dengan Kementrian Sosial atau Anggaran Pendapatan dan Belanja Daerah (APBD) dengan melakukan koordinasi dengan SKPD Sosial setempat bila di daerah. Sumber-sumber lain dapat dipergunakan, misal: sumbangan dari donatur yang diperuntukan kepentingan anak sebagai korban tindak pidana perdagangan.

Petugas-petugas yang ditunjuk untuk memonitor anak di dalam Panti Sosial adalah petugas pelaksana atau petugas fungsional. Petugas pelaksana atau petugas fungsional, terdiri dari: pekerja sosial, psikolog, tenaga kesehatan, konselor yang ditunjuk oleh instansi atau lembaga terkait yang berkoordinasi dengan SKPD Sosial. Mereka yang berasal dari instansi/lembaga ditunjuk dari instansi/lembaga yang bersangkutan sehingga tupoksi masing-masing mengikuti dari SKPD. Monitor dilakukan dalam waktu minimal satu bulan sekali, dan dilaksanakan sampai batas minimal enam bulan.

Kedua, pemberian restitusi atau ganti rugi yang benar-benar diterima oleh keluarga atau yang mewalinya demi kepentingan anak. UU. No. 13 Tahun 2006 tentang Perlindungan Saksi dan Korban, Pasal 7 (1) Korban melalui LPSK berhak mengajukan ke pengadilan berupa: (1) a. hak atas kompensasi dalam kasus pelang-garan hak asasi manusia yang berat; $b$. hak atas restitusi atau ganti kerugian yang menjadi tanggung jawab pelaku tindak pidana. (2) Keputusan mengenai kompensasi dan restitusi di berikan oleh pengadilan. (3) Ketentuan lebih lanjut mengenai 
pemberian kompensasi dan restitusi diatur dengan Peraturan Pemerintah.

Tujuan pemberian ganti rugi tidak lain untuk mengembangkan keadilan dan kesejahteraan korban sebagai anggota masyarakat dengan tolok ukur pelaksanaannya, korban diberikan hak dan kewajiban untuk dikembangkan sebagai orang (anak juga orang). Oleh karena itu, diperlukan peraturan yang tegas, sederhana, dan mudah dimengerti, sehingga dapat dihindari diskriminasi dalam penerapan oleh penegak hukum dan intimidasi dari pihak-pihak tertentu yang lebih memperburuk kondisi korban dalam penderitaan yang berkepanjangan.

UU No. 21 Tahun 2007 tentang PTPPO, menyebutkan bahwa restitusi merupakan pembayaran ganti kerugian yang dibebankan pada pelaku berdasarkan putusan pengadilan yang berkekuatan hukum tetap kepada korban atau ahli warisnya atas penderitaan yang dialaminya. Tolok ukur untuk menentukan besar kecilnya ganti rugi tergantung pada status sosial pelaku dan korban. Tidak terdapat peraturan perundang-undang yang merumuskan secara tegas mengenai indikator besarnya ganti rugi pembayaran terhadap korban, karena tindakan perawatan psikologis sulit untuk dihitung dengan uang, dan dicantumkan dalam amar putusan pengadilan.

Sebaiknya terdapat tanggung jawab basolut (absolut liability) yang dibebankan pada pelaku. Pasal 48 UU No. 21 Tahun 2007 tentang PTPPO lebih melihat ganti kerugian dalam bentuk sejumlah uang. Selain restitusi dan kompensasi terdapat pemberian ganti rugi oleh negara sebagai bentuk perlindungan korban. Ganti kerugian oleh negara merupakan suatu pembayaran pelayanan kesejahteraan, karena negara bertanggung jawab dan berkewajiban secara moral untuk melindungi warga negaranya.

Pembuatan peraturan perundang-undangan yang mengatur penyitaan terhadap peralatan atau aset-aset perusahaan dan pendapatan dari hasil tindak pidana perdagangan orang dapat pula dilakukan. Bila memungkinkan, perundang-undangan harus memuat penetapan bahwa pendapatan sebagai hasil dari penyitaan akan dipergunakan untuk kepentingan-kepen- tingan korban tindak pidana perdagangan orang. Oleh karena itu, pertimbangan ini dimaksudkan untuk membentuk atau mengumpulkan dana kompensasi bagi korban-korban tindak pidana perdagangan orang dengan memanfaatkan asetaset yang telah disita. Peraturan perundang-undangan tersebut dibuat dalam bentuk undangundang sehingga berlaku secara nasional.

Ketiga, pemulihan kondisi fisik maupun psikhis anak sebagai korban yang dilakukan dengan pendampingan psikhiater dan pengawasan oleh aparat pemerintah sampai anak dapat bersosialisasi kembali di masyarakat sehingga diperlukan sistem monitoring yang praktis dan berkesinambungan. Pada dasarnya korban kejahatan merupakan pihak yang paling menderita di dalam suatu tindak pidana perdagangan, di mana mereka tidak memperoleh perlindungan sebanyak dan sesuai yang mereka inginkan daripada perlindungan yang diberikan berdasarkan undang-undang kepada pelaku kejahatan. Adapun korban tindak pidana perdagangan anak mengalami penderitaan secara materi, fisik, psikologi serta sosial. Jadi akibat penderitaan yang dialami oleh korban, penderitaan psikologis yang dirasakan paling berat dibandingkan dengan korban tindak pidana perdagangan yang mengalami penderitaan kerugian secara materi. Penderitaan psikhis membutuhkan waktu yang lama sampai anak dapat bersosialisasi kembali dalam lingkungan masyarakat.

Penderitaan psikhis yang dialami oleh anak sebagai akibat tindak pidana perdagangan, mengakibatkan gangguan pada psikhis atau kejiwaan, mulai dari tingkat yang paling ringan sampai yang berat. Termasuk dalam cakupan penderitaan ini adalah munculnya rasa takut, gelisah, dan cemas sebagai akibat dari pengalaman menjadi target kejahatan. Korban berhak mendapatkan bantuan yang berupa bantuan rehabilitasi psikososial, yang merupakan bantuan yang diberikan oleh psikolog kepada korban yang menderita trauma atau masalah kejiwaan lainnya untuk memulihkan kembali kondisi kejiwaan korban.

Bahaya kerugian fisik, psikologis dan psikososial yang secara khusus diderita oleh korban perdagangan anak dan bertambahnya ke- 
rentanan anak terhadap eksploitasi, mensyaratkan bahwa mereka ditangani secara terpisah dari kasus orang-orang dewasa. Kepentingan utama anak harus menjadi pertimbangan dalam setiap tindakan yang menyangkut anak-anak. UU. No. 13 Tahun 2006 tentang Perlindungan Saksi dan Korban, Pasal 6 menyebutkan bahwa korban dalam pelanggaran hak asasi manusia yang berat, selain berhak atas hak sebagaimana dimaksud dalam Pasal 5, juga berhak untuk mendapatkan: (1) bantuan medis; dan (2) bantuan rehabilitasi psiko-sosial.

Pemerintah bekerjasama dengan instansi, Lembaga-lembaga Swadaya Masyarakat, Rumah Sakit, akademisi/peneliti, psikhiater dan dokter (organisasi profesi), polisi, petugas-petugas RT/ RW/Kelurahan, tokoh masyarakat. Sumber dana berasal dari APBN, APBD dan dari SKPD atau Instansi terkait. Petugas monitoring ditunjuk dari pegawai di Pusat Pelayanan Terpadu baik di Pusat maupun Daerah, bekerjasama dengan SKPD Sosial.

Sistem monitoring yang praktis dan berkesinambungan, meliputi: monitoring administratif dan monitoring tahapan-tahapan pelayanan, adalah: (1) Monitoring Administratif menguraikan kegiatan tata usaha untuk mendukung pemulihan kondisi fisik dan psikhis anak sebagai korban perdagangan orang. Antara lain: (a) penyusunan program kegiatan yang berkesinambungan, (b) pendokumentasian file data-data korban, (c) pembuatan laporan, dan (d) evaluasi perkembangan; (2) Monitoring tahapan-tahapan Pelayanan dalam upaya pemulihan kondisi korban. Antara lain: (a) korban dapat datang sendiri atau melalui rujukan/pemulangan pusat pelayanan terpadu di daerah, selanjutnya dilaksanakan proses identifikasi guna pendataan dan penyusunan rencana intervensi yang akan dilakukan sesuai kebutuhan korban. Korban ditempatkan di tempat atau rumah singgah sebelum dikembalikan kepada keluarganya, (b) penyediaan file rekaman dan kertas kerja monitoring kasus dari anak korban perdagangan, (c) penyusunan aturan kerja para pelaksana monitoring, seperti: daftar kehadiran dan jadual kegiatan, (c) pembahasan dan Penanganan kasus, (d) melakukan kunjungan ke rumah secara periodik untuk meli- hat kondisi korban; (3) Pembuatan Peraturan Daerah tentang pencegahan dan perlindungan perdagangan orang.

Peran pemerintah propinsi, kabupaten/ kota sangat strategis mengingat kejadian perdagangan orang berawal terjadi di wilayah hukum pemerintah daerah tersebut. Untuk itu, diperlukan kemampuan dan kapasitas bagi pengembangan peraturan daerah sebagai turunan peraturan perundang-undangan di tingkat nasional dalam memaksimalkan perlindungan, terutama anak.

Pemerintah propinsi dan kabupaten/kota untuk mencegah dan melindungi korban perdagangan orang, dapat mengeluarkan Peraturan Daerah dan mengembangkan peraturan daerah untuk membentuk gugus tugas daerah, melaksanakan rencana aksi daerah dan mengalokasikan anggaran untuk penyediaan layanan. Dalam membuat kebijakan-kebijakan tersebut, mereka harus merujuk pada UU. No. 21 Tahun 2007 tentang PTPPO dan peraturan pelaksanaannya yaitu PP. No. 9 Tahun 2008 serta Rencana Aksi Nasional sebagai acuan aktivitasnya.

UU No. 32 Tahun 2004 tentang Pemerintah Daerah menyebutkan bahwa pembentukan peraturan daerah dimaksudkan untuk menegaskan tugas, wewenang, kewajiban dan tanggungjawab pemerintah daerah dalam melaksanakan peraturan perundang-undangan yang lebih tinggi, dalam hal ini UU No. 21 Tahun 2007 tentang PTPPO. Sementara itu, UU No.12 Tahun 2011 tentang Pembentukan Peraturan Perundang-undangan mengatur mengenai bagaimana membuat suatu peraturan, yang dijelaskan mulai dari prosedur persiapan, mengembangkan mekanisme hukum, teknik penyusunan, sampai pembahasan dan pengesahannya. Lebih lanjut dalam Peraturan Menteri Dalam Negeri No. 16 Tahun 2006 tentang Prosedur Penyusunan Produk Hukum Daerah dilaksanakan agar pembuatan peraturan daerah terdapat keseragaman.

Peraturan Daerah merupakan salah satu bentuk peraturan pelaksana undang-undang. Kewenangannya mengatur bersumber dari kewenangan yang ditentukan oleh pembentuk undang-undang. Akan tetapi, dalam hal-hal tertentu, peraturan daerah juga dapat mengatur sen- 
diri hal-hal yang meskipun tidak didelegasikan secara eksplisit kewenangannya oleh undang-undang, tetapi perlu diatur oleh daerah untuk melaksanakan otonomi daerah yang seluas-luasnya sebagaimana dimaksud oleh Pasal 18 ayat (3) dan (4) UUD 1945.

Materi muatan peraturan daerah adalah: (a) seluruh materi yang dibutuhkan dalam rangka menyelenggarakan otonomi daerah dan tugas pembantuan; (b) menampung kondisi-kondisi yang bersifat khusus di daerah; (c) menjabarkan ketentuan peraturan perundang-undangan yang lebih tinggi, yaitu: Peraturan Presiden, Peraturan Pemerintah, dan Undang-undang atau Peraturan Pemerintah pengganti Undang-undang. ${ }^{13}$ Pembuatan Peraturan Daerah yang mengatur pencegahan dan perlindungan hukum terhadap korban perdagangan, terutama anak yang mengacu kepada UU. No. 21 Tahun 2007 tentang PTPPO.

Kepentingan utama anak harus menjadi perhatian di dalam setiap tindakan yang menyangkut anak-anak sebagai korban perdagangan. Anak yang menjadi korban perdagangan orang harus diberikan bantuan dan perlindungan yang tepat, dan hak-hak serta kebutuhan-kebutuhannya harus diperhatikan secara penuh. Model yang sebaiknya saat ini dikembangkan guna memaksimalkan perlindungan terhadap anak adalah menempatkan anak di dalam keluarga dan panti sosial, dimana merupakan lingkungan yang memberi rasa aman dengan dimonitor oleh petugas-petugas, yang telah ditunjuk oleh pemerintah daerah sehingga anak tidak lagi menjadi korban; dan pembuatan Peraturan Daerah tentang pencegahan dan perlindungan perdagangan orang.

\section{Penutup}

Simpulan

Model perlindungan korban yang tepat untuk dikembangkan adalah sebagai berikut. Pertama, menempatkan anak di dalam keluarga dan panti sosial, dimana merupakan lingkungan yang memberi rasa aman dengan dimonitor oleh

13 Lihat Pasal 14 UU. No. 12 Tahun 2011 yang menentukan "Materi muatan Peraturan Daerah adalah seluruh materi muatan dalam rangka penyelenggaraan otonomi daerah petugas-petugas, yang telah ditentukan oleh pemerintah daerah sehingga anak tidak lagi menjadi korban. Kedua, pemberian restitusi atau ganti rugi yang benar-benar diterima oleh keluarga atau yang mewalinya demi kepentingan anak.

Ketiga, pemulihan kondisi fisik maupun psikis anak sebagai korban yang dilakukan dengan pendam-pingan psikhiater dan pengawasan oleh aparat pemerintah sampai anak dapat bersosialisasi kembali di masyarakat sehingga diperlukan sistem monitoring yang praktis dan berkesinambungan. Keempat, pembuatan Peraturan Daerah tentang pencegahan dan perlindungan korban perdagangan orang.

\section{Saran}

Kabupaten/Kota merupakan wilayah yang sangat strategis mengingat kejadian perdagangan orang berasal dari wilayah hukum pemerintah daerah tersebut. Oleh karena itu, diperlukan kemampuan dan kapasitas untuk pembuatan Peraturan Daerah khususnya mengenai pencegahan dan perlindungan korban perdagangan orang dalam memaksimalkan perlindungan hukum terhadap anak yang menjadi korban tindak pidana perdagangan.

\section{Daftar Pustaka}

Agusman, Damos Dumoli. 2010. Hukum Perjanjian Internasional-Kajian Teori dan Praktik Indonesia. Bandung: Refika Aditama;

Bruckert, Christine and Colette Parent. 2002. Trafficking In Human Beings and Organized Crime: A Literature Review. Research and Evaluation Branch Community, Contract and Aboriginal Policing Services Directorate Royal Canadian Mounted Police;

Busch-Armendariz, Noel B., et al. "Human Trafficking Victims and Their Children: Assessing Needs, Vulnerabilities, Strengths, and Survivorship". Journal of Applied Research on Children: Informing Policy for Children at Risk. Vol. 2, Issue 1 Human Trafficking. Published by Digital Commons@The Texas Medical Centre;

dan tugas pembantuan, dan menampung kondisi khusus daerah serta penjabaran lebih lanjut Peraturan perundang-undangan yang lebih tinggi”. 
Colby, Ira. "Runaway and Throwaway Youth: Time for Policy Changes and Public Responsibility". Journal of Applied Research on Children: Informing Policy for Children at Risk. Vol. 2. Issue 1: Human Trafficking. Published by DigitalCommons@ The Texas Medical Centre;

Coontz, Phyllis and Catherine Griebel. "International Approaches to Human Trafficking: The Call for a Gender-Sensitive Perspective in International Law". Women's Health Journal. Vol. 4. 2004;

Freeman. Michael D. A. 1997. The Moral Status of Children: Essays on the Rights of the Child. Martinus Nijhoff Publishers;

Gosita. Arif. "Aspek Hukum Perlindungan Anak dan Konvensi Hak-hak Anak". Era Hukum. Jurnal Ilmiah Ilmu Hukum. No. 4/Th.V/ April 1999. Jakarta: Fakultas Hukum Tarumanegara;

Manan. Bagir. "Penelitian di Bidang Hukum". Jurnal Hukum Puslitbangkum No. 1 - 1999. Pusat Penelitian Perkembangan Hukum. Bandung: UNPAD;

Rafferty. Yvonne. "The Impact of Trafficking on Children: Psychological and Social policy Perspectives". Journal Compilation: Child Development Perspectives. Vol. 2. Number 1. 2008;

Tiefenbrun. Susan. "Child Soldiers. Slavery and the Trafficking of Children". Fordham International Law Journal. Vol. 31. Issue 2. The Berkely Electronic Press (bepress). 2007;

Van Bueren. Geraldine. The International Law on the Rights of the Child. International Studies in Human Rights Volume 35. Martinus Nijhoff Publishers. 1998;

Widiartana. 2009. Viktimologi Perspektif Korban Penanggulangan Kejahatan. Yogyakarta: Universitas Atma Jaya. 